\title{
UK Renal Registry 12th Annual Report (December 2009): Chapter 8 Adequacy of Haemodialysis in UK Renal Centres in 2008: national and centre-specific analyses
}

\author{
Andrew J Williams ${ }^{a}$, Clare Castledine ${ }^{b}$, Anna Casula ${ }^{b}$ and Graham Warwick ${ }^{c}$ \\ ${ }^{a}$ Morriston Hospital, Swansea, UK; ${ }^{b}$ UK Renal Registry, Bristol, UK; ${ }^{c}$ Leicester General Hospital, Leicester, UK
}

\section{Key Words}

Haemodialysis · Adequacy · Urea reduction ratio

\begin{abstract}
Background: Outcome in patients treated with haemodialysis (HD) is influenced by the delivered dose of dialysis. The UK Renal Association (RA) publishes Clinical Practice Guidelines which include recommendations for dialysis dose. The urea reduction ratio (URR) is a widely used measure of dialysis dose. Aim: To determine the extent to which patients received the recommended dose of HD in the UK. Methods: Seventy-two renal centres in the UK submit data electronically to the UK Renal Registry (UKRR). Two groups of patients were included in the analyses: the prevalent patient population on 31st December 2008 and the incident patient population for 2008. Centres returning data on $<50 \%$ of their patient population were excluded from centre-specific comparisons. Results: Data regarding URR were available from 62 renal centres in the UK. Fifty-one centres provided URR data on more than $90 \%$ of prevalent patients. There has been an increase from $56 \%$ in 1998 to $83 \%$ in 2008 in the proportion of patients in the UK who met the UK Clinical Practice Guideline for URR $(>65 \%)$. There was considerable variation from one centre to another, with 9 centres attaining the RA clinical practice
\end{abstract}

\section{KARGER}

Fax +4161306 1234 E-Mail karger@karger.ch www.karger.com guideline in $>90 \%$ of patients and 5 centres attaining the standard in $<70 \%$ of patients. The HD dose (URR) delivered to patients who had just started dialysis treatment was lower than that of patients who had been treated for longer and increased further with time. Conclusions: The delivered dose of HD for patients with established renal failure has increased over 10 years. Whilst the large majority of patients in the UK achieved the target URR there was considerable variation between centres in the percentage of patients achieving this.

\section{Introduction}

Amongst patients with established renal failure the delivered dose of HD is an important predictor of outcome [1] which has been shown to influence survival [2-4]. It depends on treatment (duration and frequency of dialysis, dialyser size, dialysate and blood flow rate) and patient (size, weight, haematocrit and vascular access) characteristics [5]. The two widely accepted measures of urea clearance are $\mathrm{Kt} / \mathrm{V}$, the ratio between the product of urea clearance $(\mathrm{K}, \mathrm{in} \mathrm{ml} / \mathrm{min})$ and dialysis session duration ( $\mathrm{t}$, in minutes) divided by the volume of distribution of urea in the body $(\mathrm{V}$, in $\mathrm{ml})$; and URR,

Andrew J Williams

UK Renal Registry, Southmead Hospital, Southmead Road, Bristol, BS10 5NB, UK

Email: andrew.williams2@abm-tr.wales.nhs.uk 
derived solely from the percentage fall in serum urea (URR) during a dialysis treatment. Kt/V takes into account the contribution of ultrafiltration to urea clearance and is therefore a more accurate descriptor of urea clearance. However, accurate calculation of $\mathrm{Kt} / \mathrm{V}$ requires iterative computerised modelling [6] and although it can be estimated using one of several formulae [7], these all require additional data items over and above pre- and post-dialysis urea concentration, including the duration of the dialysis treatment and the ultrafiltration volume. URR has been shown to correlate with survival even though it does not take account of the contribution made by residual renal function and ultrafiltration to urea clearance $[2,3]$.

Further analysis of the data [8] from the National Cooperative Dialysis Study [1] suggested that outcome was improved by maintaining a Kt/V greater than 1.2. However, the HEMO study [9] suggested that there was no benefit accrued by increasing HD dose further. In that study, survival of patients undergoing thrice weekly HD in whom a URR of $75 \%$ (equilibrated $\mathrm{Kt} / \mathrm{V}$ of 1.45) was achieved was not significantly better than in those who had a URR of $65 \%$ (equilibrated Kt/V of $1.05)$, suggesting that there was a 'ceiling effect' to the survival benefit of higher dialysis doses when achieved using thrice weekly haemodialysis.

Based on published evidence, clinical practice guidelines have been developed by various national and regional organisations (www.kdigo.org). There is considerable uniformity between them with regard to the recommendations for minimum dose of dialysis although there are differences in the methodology advised [10-13].

A recent survey undertaken by the Quality European Studies (QUEST) initiative has reported that URR is the most common method used to assess small solute removal in HD patients in Europe with equilibrated $\mathrm{Kt} / \mathrm{V}$ being used in a minority of centres [14].

The UKRR is part of the RA and provides audit and analysis of renal replacement therapy in the UK. It receives quarterly electronic extracts covering a range of data items from information systems within each renal centre. As most centres do not report duration of dialysis or weight loss during dialysis, the UKRR has chosen URR rather than $\mathrm{Kt} / \mathrm{V}$ for comparative audit of haemodialysis adequacy.

Several centres in the UK now use online measurement of ionic dialysance to measure clearance of small molecules during HD relying on studies that have demonstrated a close linear relationship between this measure and conventional measures of urea clearance $[15,16]$. However, the UKRR strongly encourages these centres to continue to perform and report conventional pre- and post-dialysis measurements of blood urea concentration at least on a 3-monthly basis to allow comparative audit.

The main objective of this study was to determine the extent to which patients undergoing HD treatment for established renal failure in the UK received the dose of $\mathrm{HD}$ recommended in the UK RA clinical practice guidelines [11].

\section{Methods}

Seventy-two renal centres in the UK submit data electronically to the UKRR on a quarterly basis [17]. The majority of these centres have satellite units but for the purposes of this study the data from the renal centres and their associated satellite units were amalgamated. Two groups of patients were included in the analyses. Firstly, analysis was undertaken using data from the prevalent HD patient population on 31st December 2008. For this analysis, data for URR were taken from the last quarter of 2008 unless that data point was missing in which case data from the 3rd quarter were taken. As the prevalent population only included those patients alive on December 31st, data from those patients who had died before that date have not been included in the analysis. The second analysis involved the patients who had started treatment with HD (incident patient population) during 2008. For these patients, analysis was undertaken using the last recorded URR during the quarter in which the patient had started dialysis. Data from patients known to be receiving more or less than thrice weekly HD were omitted from analysis. However, because not all centres report frequency of $\mathrm{HD}$, it is possible that data from a small number of patients receiving HD less or more frequently than thrice weekly were included in the analyses.

Analysis of the data from both groups of patients included calculation of the median URR and of the proportion of patients who had achieved the RA standard (as outlined below) in each of the renal centres as well as for the country as a whole.

All patients with data were included in the statistical analysis at a national level, although centres with fewer than 20 patients, or providing less than $50 \%$ data completeness were excluded from the comparison between centres.

The UK RA Clinical Practice Guidelines [11] in operation at the time these data were collected were as follows:

HD should take place at least three times per week in nearly all patients. Reduction of dialysis frequency to twice per week because of insufficient dialysis facilities is unacceptable. Every patient receiving thrice weekly $H D$ should have consistently:

- either URR $>65 \%$

- or equilibrated $\mathrm{Kt} / \mathrm{V}(\mathrm{eKt} / \mathrm{V})$ of $>1.2$ (or single pool Kt/V of $>1.3$ ) calculated from pre- and post-dialysis urea values, duration of dialysis and weight loss during dialysis). 
To achieve a URR above $65 \%$ or $\mathrm{eKt} / \mathrm{V}$ above 1.2 consistently in the vast majority of the haemodialysis population clinicians should aim for a minimum target URR of 70\% or minimum eKt/V of 1.4 in individual patients.

The duration of thrice weekly HD in adult patients with minimal residual renal function should not be reduced below 4 hours without careful consideration.

Patients receiving dialysis twice weekly for reasons of geography should receive a higher sessional dose of dialysis. If this cannot be achieved, then it should be recognised that there is a compromise between the practicalities of dialysis and the patient's long-term health.

Measurement of the 'dose' or 'adequacy' of HD should be performed monthly in all hospital HD patients and may be performed less frequently in home HD patients. All dialysis units should collect and report this data to their regional network and the UKRR.

Post-dialysis blood samples should be collected either by the slow-flow method, the simplified stop-flow method, or the stop dialysate flow method. The method used should remain consistent within renal units and should be reported to the Registry.

The RA clinical practice guidelines for HD dose apply specifically to patients undergoing thrice weekly HD. In these patients it is recommended that blood for biochemical measurement (including pre-dialysis urea for URR) should be taken before the mid week dialysis session [11]

A potentially confounding factor is the methodology used for taking the post dialysis blood sample. Advice given to renal centres following a postal survey in 2002 [18] aimed to achieve uniformity and this was reflected in the RA standards [19]. These recommended that the post dialysis blood samples should be collected either by the stop flow method, the simplified stop flow method or the stop-dialysate-flow method. No reliable data were available to clarify whether the important variations in post-dialysis sampling methodology that were identified at that time persist.

\section{Results}

\section{Data completeness}

Data regarding HD dose (URR) were available from 62 of the 72 renal centres which submitted data to the UKRR (table 8.1). Data were available for $71 \%$ $(13,191)$ of the total prevalent population $(18,520)$ treated with $\mathrm{HD}$ who met the inclusion criteria for these analyses. However it was available for $92 \%$ of the prevalent HD patients treated in one of the 62 units providing any data for URR $(14,407)$. Of the total incident patient population $(4,526)$ starting $\mathrm{HD}$ during 2008 there were data available for URR for 2,278 (50\%) patients during the 3 months after they had started treatment.
Table 8.1. Percentage completeness of URR data returns

\begin{tabular}{|c|c|c|c|}
\hline Centre & $\%$ complete & Centre & $\%$ complete \\
\hline Abrdn & 97 & L Rfree & 0 \\
\hline Airdrie & 99 & L St.G & 0 \\
\hline Antrim & 98 & L West & 0 \\
\hline B Heart & 94 & Leeds & 97 \\
\hline B QEH & 96 & Leic & 98 \\
\hline Bangor & 97 & Liv Ain & 93 \\
\hline Basldn & 99 & Liv RI & 92 \\
\hline Belfast & 94 & M Hope & 57 \\
\hline Bradfd & 88 & M RI & 0 \\
\hline Brightn & 0 & Middlbr & 95 \\
\hline Bristol & 99 & Newc & 0 \\
\hline Camb & 38 & Newry & 99 \\
\hline Cardff & 90 & Norwch & 97 \\
\hline Carlis & 99 & Nottm & 97 \\
\hline Carsh & 94 & Oxford & 69 \\
\hline Chelms & 91 & Plymth & 95 \\
\hline Clwyd & 91 & Ports & 97 \\
\hline Colchr & 100 & Prestn & 81 \\
\hline Covnt & 96 & Redng & 96 \\
\hline D\&Gall & 96 & Sheff & 96 \\
\hline Derby & 99 & Shrew & 92 \\
\hline Derry & 98 & Stevng & 96 \\
\hline Donc & 100 & Sthend & 96 \\
\hline Dorset & 98 & Stoke & 0 \\
\hline Dudley & 79 & Sund & 98 \\
\hline Dundee & 0 & Swanse & 97 \\
\hline Dunfn & 94 & Truro & 98 \\
\hline Edinb & 98 & Tyrone & 99 \\
\hline Exeter & 99 & Ulster & 99 \\
\hline Glasgw & 97 & Wirral & 36 \\
\hline Glouc & 99 & Wolve & 76 \\
\hline Hull & 96 & Wrexm & 98 \\
\hline Inverns & 98 & York & 92 \\
\hline Ipswi & 100 & England & 67 \\
\hline Kent & 80 & N Ireland & 97 \\
\hline Klmarnk & 94 & Scotland & 88 \\
\hline L Barts & 0 & Wales & 93 \\
\hline L Guys & 89 & UK & 71 \\
\hline L Kings & 0 & & \\
\hline
\end{tabular}

Fifty-one centres submitted data on more than $90 \%$ of prevalent patients treated with HD. Nine centres were included in the analysis but returned data from less than $90 \%$ of patients - Bradford (88.3\%), Cardiff (89.6\%), Dudley (78.8\%), Kent (79.9\%), L Guys (89.2\%), Manchester Hope (57.4\%), Oxford (68.9\%), Preston (80.6\%) and Wolverhampton (75.6\%). Two centres (Cambridge and Wirral) reporting on less than $50 \%$ of prevalent patients were not included in the centre level analyses although the patients were included in the national analyses. URR data were not received from ten centres (Brighton, Dundee, London Barts, 


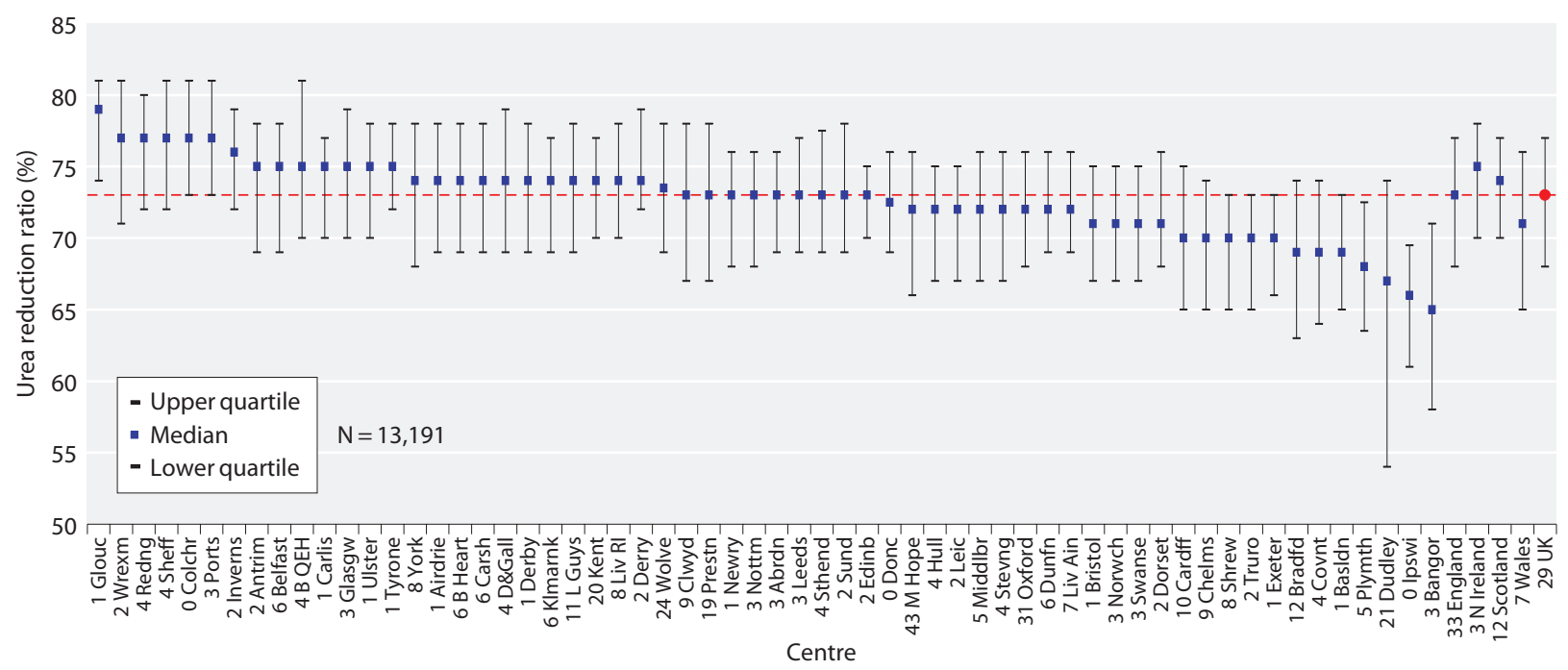

Fig. 8.1. Median URR achieved in prevalent patients in each centre, 2008

London Kings, London Royal Free, London St Georges, London West, Manchester Royal Infirmary, Newcastle and Stoke). The number preceding the centre name in each figure indicates the percentage of missing data from that centre.

Thirty-three centres submitted data regarding URR within 3 months of starting $\mathrm{HD}$ on more than 20 patients, representing more than $50 \%$ of their incident patient population.

\section{Achieved URR}

For prevalent patients, the median URR $(73 \%$ for UK; centre range $65 \%-79 \%)$ and percentage $(83 \%$ for
UK; centre range 46\%-95\%) attaining the RA standard of a URR $>65 \%$ from 60 renal centres are shown in figures 8.1 and 8.2. Figure 8.3 illustrates the close relationship between the two. With one exception (Edinburgh; median URR 73\%) all 9 centres which attained the RA standard in more than $90 \%$ of patients had a median URR of $75 \%$ or more. All centres which achieved a URR $>65 \%$ in at least $80 \%$ of patients had a median URR of at least $70 \%$. The 3 centres with a median URR of $67 \%$ or less achieved the RA standard for HD dose in less than $55 \%$ of their patients. There was considerable variation from one centre to another, with 9 centres attaining the RA clinical practice guideline

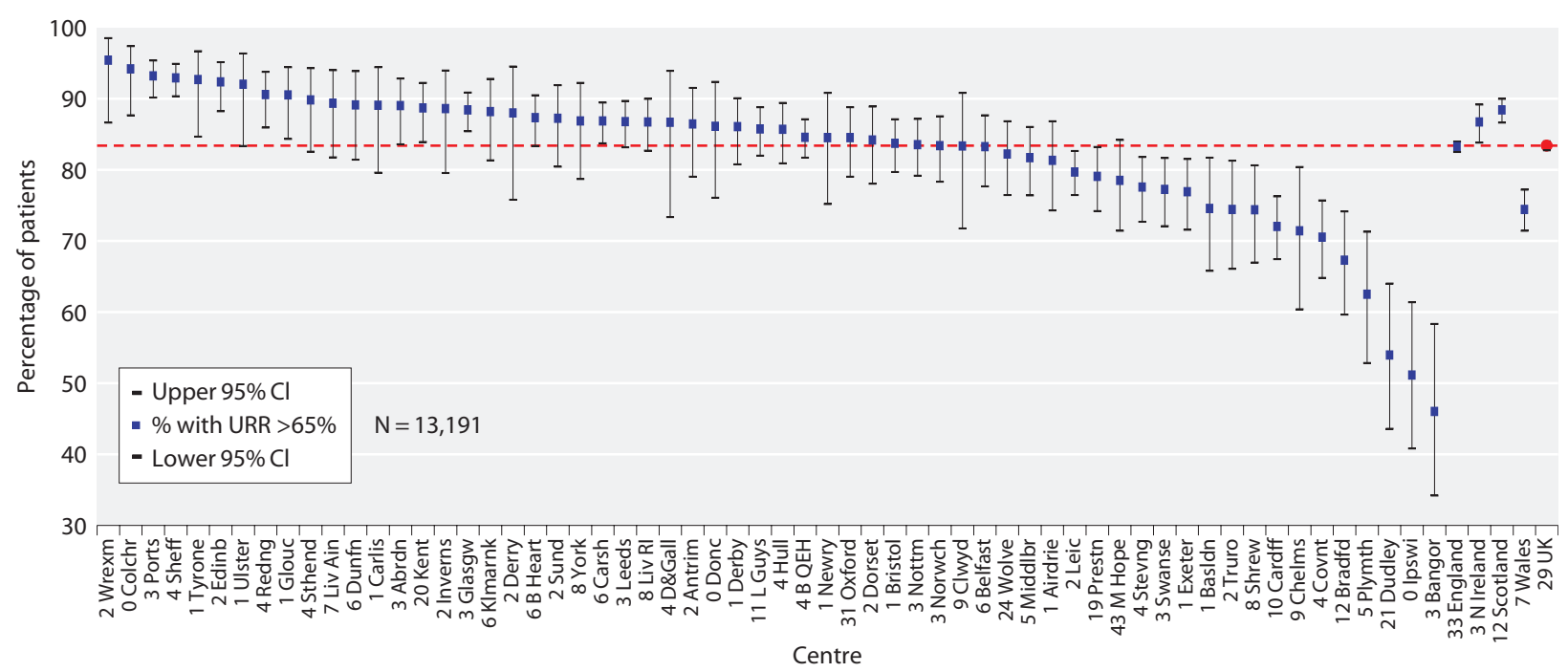

Fig. 8.2. Percentage of prevalent patients with URR $>65 \%$ in each centre, 2008 


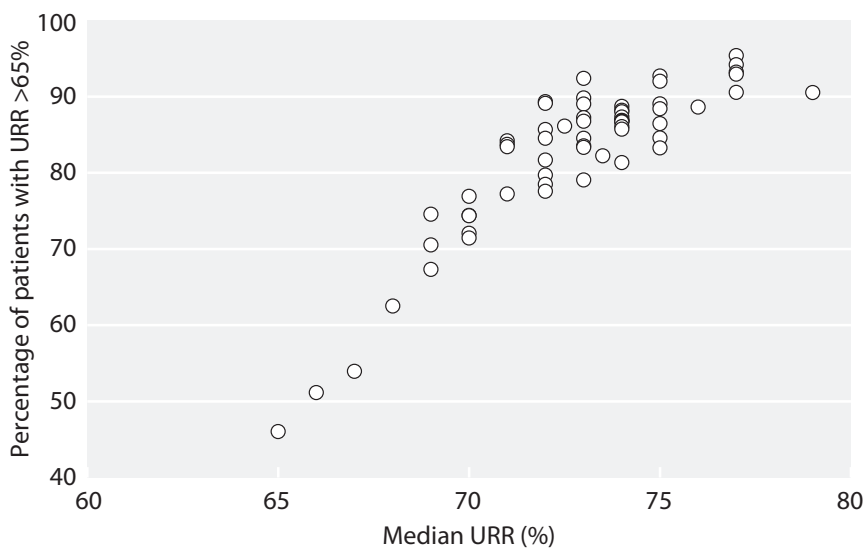

Fig. 8.3. Relationship between achievement of the Renal Association standard for URR and the median URR in each centre, 2008

in $>90 \%$ of patients and 5 centres attaining the standard in $<70 \%$ of patients.

\section{Changes in URR over time}

The change in the percentage attainment of the RA clinical practice guidelines (URR $>65 \%$ ) and the median URR for the UK from 1998 to 2008 are shown in figure 8.4. Northern Ireland has provided data since 2005 and is included in these analyses.

The proportion of patients attaining the RA standard has increased from $56 \%$ to $83 \%$ whilst the median URR has risen from $67 \%$ to $73 \%$ during the same time period.

\section{Variation of achieved URR with time on dialysis}

The proportion of patients who attained the RA standard for HD adequacy increased in line with the time since those patients started HD (figure 8.5). Of those dialysed for less than 6 months, $68 \%$ had a URR $>65 \%$ whilst $87 \%$ of patients who had been dialysed for more than two years attained the standard in 2008 .

The median URR during the first quarter after starting HD treatment of the incident HD population in the UK in 2008 was $65 \%$ (figure 8.6).

\section{Discussion}

The dose of delivered HD is widely recognised as having an important influence on outcome in patients treated with chronic HD. Although data regarding URR were only available to the UKRR on $71 \%$ of the total prevalent UK HD population they were available from $92 \%$ of the prevalent patient population treated in any one of 62 of the 72 renal centres which had provided any data. In some of those centres providing data, failure to achieve $100 \%$ data return was likely to have arisen in part from a lack of electronic linkage between satellite units and the main renal centre database.

The proportion of patients achieving the RA standard for URR has increased steadily during the 10 years since 1998. This observation is also consistent when patients are grouped on the basis of length of time since starting HD treatment. Over $80 \%$ of patients in the UK achieved the target of a URR $>65 \%$ and of patients who had been treated with HD for more than 2 years $87 \%$ achieved the target. The figure for patients during the first 6 months after starting treatment was lower $(68 \%)$ but in these

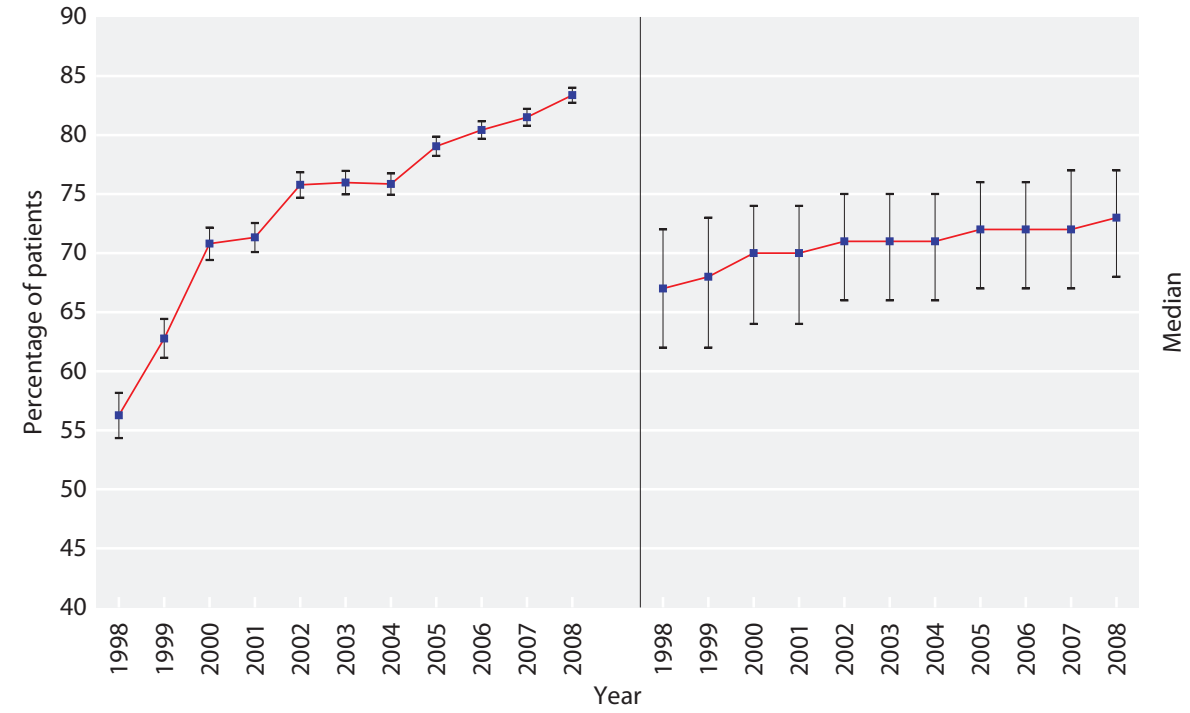

Fig 8.4. Change in the percentage of patients with URR $>65 \%$ and the median URR between 1998 and 2008 in the UK 
Fig 8.5. Percentage of prevalent haemodialysis patients achieving URR $>65 \%$ against duration on haemodialysis between 1999 and 2008

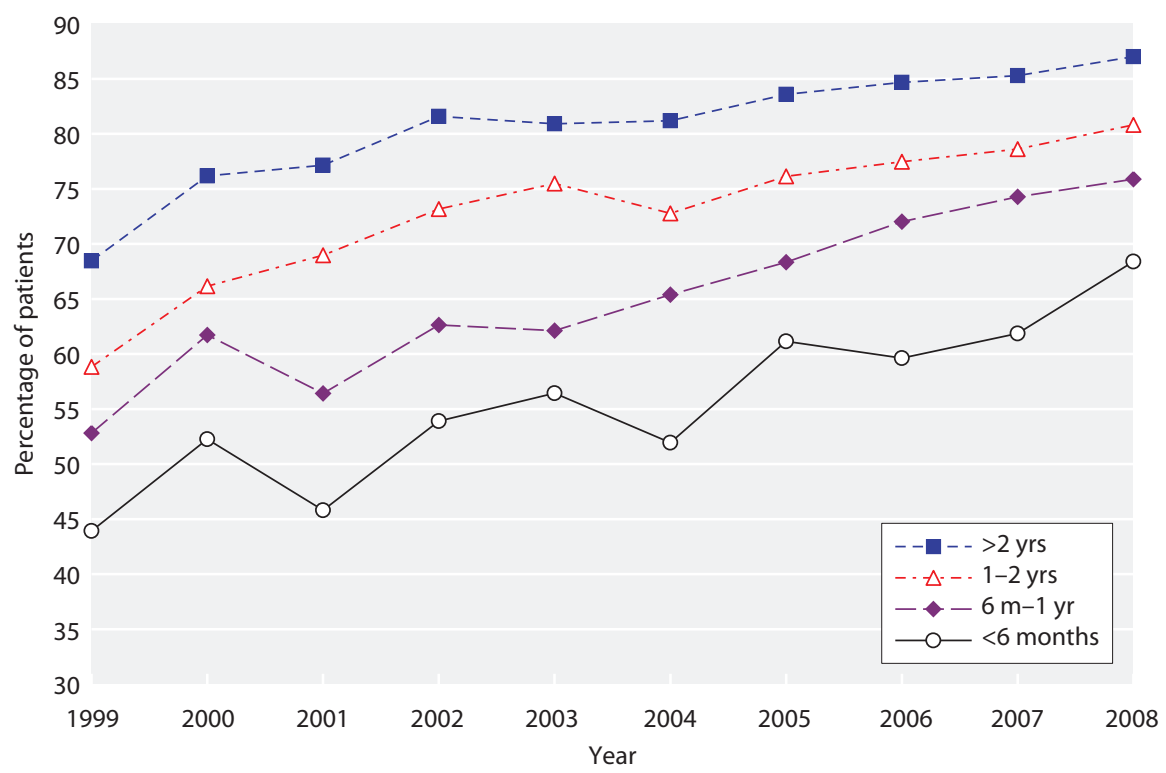

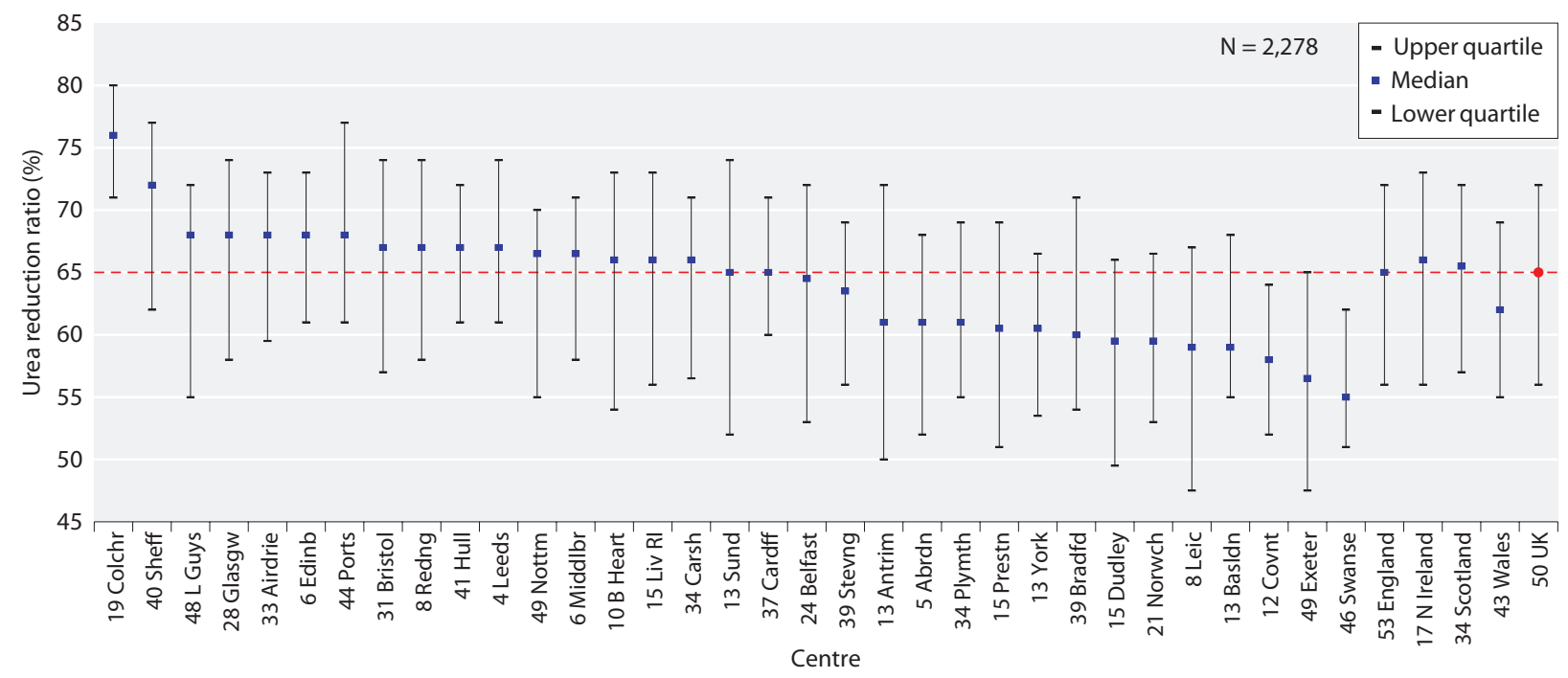

Fig 8.6. Median URR in the first quarter after starting RRT in patients who started haemodialysis in 2008

patients a high proportion will have residual renal function to compensate.

There was a wide range (46\%-95\%) of achievement of the RA standard (URR >65\%) between different centres which is likely to reflect genuine differences in HD dose although inconsistency in sampling methodology for the post dialysis urea sample may play a part [18]. Duration of HD sessions has been shown to have a major influence and current UK RA clinical practice guidelines recommend that 'the duration of thrice weekly HD in adult patients with minimum residual function should not be reduced below 4 hours without careful consideration'.

The median URR of patients undergoing HD in the UK in 2008 was $73 \%$ (centre range of $65 \%-79 \%$ ). In order to consistently achieve a URR $>65 \%$ the UK RA clinical practice guidelines recommend that clinicians should aim for a minimum target URR of $70 \%$ and this approach is supported by the findings in this study. Those units which achieved the UK RA standard in more than $90 \%$ of patients had a median URR of $73 \%$ or more. 
Furthermore, recent studies have suggested that prescription of a target $\mathrm{Kt} / \mathrm{V}$ of 1.2 in females and small males underestimates the required dose [20]. These observations support the K-DOQI guidelines for HD which advise an increase in the minimum dialysis dose target for women and small men [21] and are reflected in the advice given in the UK RA Clinical Practice Guidelines [11].

The use of urea clearance for measurement of HD dose is criticised by some [22] arguing that outcome is improved by longer treatment time independently of urea removal [5, 23-27] and that clearance of 'middle molecules' has an important impact [28, 29]. Furthermore, residual renal function can improve outcome in incremental HD despite reduced dialysis dose [30] although preservation of residual renal function should not be seen as a primary goal [31].

However, no consensus has yet emerged on alternative markers of HD dose and whilst this is the case the UKRR will continue to audit HD adequacy on the basis of urea clearance as assessed by URR.

Conflict of interest: none

\section{References}

1 Gotch FA, Sargent JA: A mechanistic analysis of the National Cooperative Dialysis Study (NCDS). Kidney Int 1985;28:526-534.

- 2 Owen WF, Lew NL, Liu Y, Lowrie EG, Lazarus JM: The Urea Reduction Ratio and Serum Albumin Concentration as Predictors of Mortality in Patients Undergoing Hemodialysis. N Engl J Med 1993;329:1001-1006.

3 Held PJ, Port FK, Wolfe RA, Stannard DC, Carroll CE, Daugirdas JT, Bloembergen WE, Greer JW, Hakim RM: The dose of hemodialysis and patient mortality. Kidney Int 1996;50:550-556.

-4 Tentori F, Hunt WC, Rohrscheib M, Zhu M, Stidley CA, Servilla K, Miskulin D, Meyer $\mathrm{KB}$, Bedrick EJ, Johnson HK, Zager PG: Which Targets in Clinical Practice Guidelines Are Associated with Improved Survival in a Large Dialysis Organization? J Am Soc Nephrol 2007;18:2377-2384.

5 Locatelli F, Buoncristiani U, Canaud B, Kohler $\mathrm{H}$, Petitclerc T, Zucchelli P: Dialysis dose and frequency. Nephrol Dial Transplant 2005;20: 285-296.

6 Depner TA: Assessing adequacy of hemodialysis: urea modeling. Kidney Int 1994;45: 1522-1535.

7 Movilli E: Simplified approaches to calculate Kt/V. It's time for agreement. Nephrol Dial Transplant 1996;11:24-27.

8 Keshaviah P: Urea kinetic and middle molecule approaches to assessing the adequacy of hemodialysis and CAPD. Kidney Int Suppl 1993;40:S28-S38.

-9 Eknoyan G, Beck GJ, Cheung AK, Daugirdas JT, Greene T, Kusek JW, Allon M, Bailey J, Delmez JA, Depner TA, Dwyer JT, Levey AS, Levin NW, Milford E, Ornt DB, Rocco MV, Schulman G, Schwab SJ, Teehan BP, Toto R, the Hemodialysis Study Group: Effect of Dialysis Dose and Membrane Flux in Maintenance Hemodialysis. N Engl J Med 2002; 347:2010-2019.

- 10 Vanbelleghem H, Vanholder R, Levin NW, Becker G, Craig JC, Ito S, Lau J, Locatelli F,
Zoccali C, Solez K, Hales M, Lameire N, Eknoyan G: The Kidney Disease: Improving Global Outcomes website: Comparison of guidelines as a tool for harmonization. Kidney Int 2007;71:1054-1061.

11 UK Renal Association Clinical Practice Guidelines Committee. 2007 Module 3a Haemodialysis, 2007 http://www.renal.org/ guidelines/module3a.html.

12 European Best Practice Guidelines Expert Group on Haemodialysis. Nephrol Dial Transplant 2002;17(suppl 7):S16-S31.

13 NKF-KDOQI clinical practice guidelines; update 2006. Am J Kidney Dis 2006;48 (Suppl 1):S2-S90.

14 Coucoud C, Jager KJ, Tomson C, Cabanne J-F, Collart F, Finne P, de Francisco A, Frimat L, Garneata L, Leivestad T, Lemaitre V, Limido A, Ots M, Resic H, StojcevaTaneva O, Kooman J: Assessment of urea removal in haemodialysis and the impact of the European Best Practice Guidelines. Nephrol Dial Transplant 2009;24:1267-1274.

15 Lowrie EG, Li Z, Ofsthun NJ, Lazarus JM: Evaluating a new method to judge dialysis treatment using online measurements of ionic clearance. Kidney Int 2006;70:211-217.

16 Lindley EJ, Chamney PW, Wuepper A, Ingles $\mathrm{H}$, Tattersall JE, Will EJ: A comparison of methods for determining urea distribution volume for routine use in on-line monitoring of haemodialysis adequacy. Nephrol Dial Transplant 2009;24:211-216.

17 Ansell D, Tomson CR. UK Renal Registry 11th Annual Report (December 2008) Chapter 15 The UK Renal Registry UKRR database, validation and methodology. Nephron Clin Pract 2009;111:Suppl 1c:277-85.

18 Will E: Adequacy of haemodialysis (urea reduction ratio) Chapter 7; in Ansell D, Feest $\mathrm{T}$ (eds): UK Renal Registry 5th Annual Report, 2002, pp 85-100.

19 UK Renal Association Standards and Audit subcommittee. Treatment of adults and children with renal failure. 3rd edition.
Chapter 3. Haemodialysis: clinical standards and targets, 2002 http://www.renal.org/ standards/renalstandards_2002b.pdf

20 Spalding EM, Chandna SM, Davenport A, Farrington $\mathrm{K}: \mathrm{Kt} / \mathrm{V}$ underestimates the hemodialysis dose in women and small men. Kidney Int 2008;74:348-355.

21 Clinical practice guidelines for hemodialysis adequacy, update 2006. Am J Kidney Dis 2006;48(suppl 1):S2-S90.

22 Vanholder R, Eloot S, Van Biesen W: Do we need new indicators of dialysis adequacy based on middle-molecule removal? Nature Clinical Practice Nephrology 2008;4:174-175.

- 23 Tattersall J, Martin-Malo A, Pedrini L, Basci A, Canaud B, Fouque D, Haage P, Konner K, Kooman J, Pizzarelli F, Tordoir J, Vennegoor M, Wanner C, ter Wee P, Vanholder R: EBPG guideline on dialysis strategies. Nephrol Dial Transplant 2007;22:ii5-21.

24 Saran R, Bragg-Gresham JL, Levin NW, Twardowski ZJ, Wizemann V, Saito A, Kimata N, Gillespie BW, Combe C, Bommer J, Akiba T, Mapes DL, Young EW, Port FK: Longer treatment time and slower ultrafiltration in hemodialysis: Associations with reduced mortality in the DOPPS. Kidney Int 2006;69:1222-1228.

25 Marshall MR, Byrne BG, Kerr PG, McDonald SP: Associations of hemodialysis dose and session length with mortality risk in Australian and New Zealand patients. Kidney Int 2006;69:1229-1236.

26 Eloot S, Van Biesen W, Dhondt A, Van de Wynkele H, Glorieux G, Verdonck P, Vanholder R: Impact of hemodialysis duration on the removal of uremic retention solutes. Kidney Int 2007;73:765-770.

27 Basile C, Lomonte C: Dialysis time is the crucial factor in the adequacy of hemodialysis. Kidney Int 2008;74:965-966.

28 Eloot S, Torremans A, De Smet R, Marescau B, De Deyn PP, Verdonck P, Vanholder R: Complex Compartmental Behavior of Small Water-Soluble Uremic Retention Solutes: 
Evaluation by Direct Measurements in Plasma and Erythrocytes. Am J Kidney Dis 2007;50:279-288.

29 Lowrie EG: The Kinetic Behaviors of Urea and Other Marker Molecules During
Hemodialysis. Am J Kidney Dis 2007;50: 181-183.

- 30 Vilar E, Wellsted D, Chandna SM, Greenwood RN, Farrington K: Residual renal function improves outcome in incremental haemodialysis despite reduced dialysis dose. Nephrol Dial Transplant 2009;24:2502-2510.

31 Canaud B: Residual renal function: the delicate balance between benefits and risks. Nephrol Dial Transplant 2009;23:1801-1805. 